\begin{tabular}{|l|l|l||}
\hline \multicolumn{2}{|c|}{ PublisherInfo } \\
\hline \hline PublisherName & $:$ & BioMed Central \\
\hline \hline PublisherLocation & $:$ & London \\
\hline \hline PublisherImprintName & $:$ & BioMed Central \\
\hline \hline
\end{tabular}

\title{
Dietary changes take two years to reduce heart attack risk
}

\begin{tabular}{|l|l|l||}
\hline \multicolumn{2}{|c||}{ ArticleInfo } \\
\hline \hline ArticleID & $:$ & 53 \\
\hline \hline ArticleDOI & $:$ & $10.1186 /$ cvm-2001-71954 \\
\hline \hline ArticleCitationID & $:$ & 71954 \\
\hline \hline ArticleSequenceNumber & $:$ & 32 \\
\hline \hline ArticleCategory & $:$ & Paper Report \\
\hline ArticleFirstPage & $:$ & 1 \\
\hline \hline ArticleLastPage & $:$ & 3 \\
\hline \hline & & RegistrationDate : 2001-10-17 \\
ArticleHistory & $:$ & Received \\
\hline \hline ArticleCopyright & $:$ & Oiomed Central Ltd2001-1-19 \\
\hline \hline ArticleGrants & $:$ & \\
\hline \hline
\end{tabular}




\begin{tabular}{|l|l|l|l|}
\hline ArticleContext & $:$ & 1306322 \\
\hline
\end{tabular}

Joanna Lyford, Aff1

Corresponding Affiliation: Aff1

Aff1 MedWire, UK

Keywords

Cardiovascular diseases, cholesterol, diet

\section{Context}

Introduction

This study aimed to determine the effects of modifying dietary fat intake on the incidence of cardiovascular events.

\section{Significant findings}

Results

Alteration of dietary fat intake had little effect on total mortality (rate ratio $[R R]=0.98 ; 95 \%$ confidence interval [CI] 0.86-1.12). Cardiovascular mortality was reduced by $9 \%(\mathrm{RR}=0.91 ; 95 \% \mathrm{CI}$ $0.77-1.07)$ and cardiovascular events by $16 \%(\mathrm{RR}=0.84 ; 95 \% \mathrm{CI} 0.72-0.99)$, which was attenuated $(\mathrm{RR}=0.86 ; 95 \% \mathrm{CI} 0.72-1.03)$ in a sensitivity analysis that excluded a trial using oily fish. Trials with at least two years' follow up provided stronger evidence of protection from cardiovascular events (RR 0.76 ; $95 \%$ CI $0.65-0.90)$.

\section{Comments}

Discussion 
The authors point out that the answers presented by the trial are "not definitive", as the data are "too sparse to be convincing". But their data are broadly in line with the benefits that might be expected from modest lowering of cholesterol, and certainly provide support, at an individual if not an epidemiological level, for the central role of dietary fat intake in the causation of CV disease. "We are left with a suggestion that less total fat or less of any individual fatty acid fraction in the diet is beneficial."

\section{Methods}

The authors searched Medline and other bibliographic databases to identify randomized, placebocontrolled trials that examined the effect of reduction or modification of dietary fat intake. Twenty seven trials fulfilled the inclusion criteria, and were included in their meta-analysis. This resulted in a total of 27 studies, comprising 30,902 person years of observation, being included in the meta-analysis.

\section{Additional information}

\section{References}

1. Hooper L, Summerbell CD, Higgins JPT, Thompson RL, Capps NE, Smith GD, Riemersma RA, Ebrahim S: Dietary fat intake and prevention of cardiovascular disease: systematic review. BMJ. 2001, 322: 757-763. 